\title{
AN ANALYSIS OF THE TRANSLATION OF PROCEDURE TEXT IN ANDROID, IOS, WINDOWS OPERATING SYSTEMS MOBILE PHONES' MANUAL BOOKS
}

\author{
Wahyu Tri Kustanti and Farida Agoes \\ Politeknik Negeri Bandung
}

\begin{abstract}
The main objective of this research is to find out the translation technique mostly used in translating the same words and phrases of Android, iOS and Windows mobile phones' manual books. Its data were obtained through collecting the printed manual books and unprinted manual books from internet. The data were analyzed by using theory of translation technique by Molina \& Albir (2002). The final results of the research indicate the following. First, there are 100 similar words and phrases were found among translation of 3 OS mobile phones' manual books. Second, there are 9 translation techniques used; adaptation, amplification, borrowing, calque, establish equivalent, discursive creation, generalization, and particularization. In addition, the translation technique mostly used in translation of Android, iOS And Windows mobile phones' manual books is Calque.
\end{abstract}

Key words: Translation, Similar Words, Phrases \& Sentences, Mobile Phones' Manual Book

\section{INTRODUCTION}

In this era of globalization, translation has an important role, since it helps people to get information from many different languages. Translation is the way of communication that transfer the meaning from source language to target language. However, if translation cannot transfer meaning from source language to target language correctly or meaning distortion, it will be 
a bad translation. Therefore, this project analyzes translation for identifying whether the translation of manual books is good or not.

The translation of procedure text in manual books is the focus of this project because manual book is a text, which has the aim to guide the readers in using an object correctly and it is always written in procedure text. In reality, people usually read and try to understand the manual book first before using the new object so that they know the steps for using it correctly. It means that manual book is an important part of every product, to make people easy in using the product and know what to do if there is a damaged.

The material of the project is mobile phones' manual books. In this modern world, mobile phone is helpful within human activities. Now mobile phone has been assembled to be sophisticated mobile phone that having many features for example mobile phone operating systems Android, iOS, and Windows. Besides, automatically people will need mobile phone's manual books for guiding them to use the mobile phone correctly. For some reasons before, it is worthwhile to conduct the research about analysis of the translation of procedure text in Android, iOS, and Windows operating systems mobile phones' manual books.

The objectives of the research are:

1. To find out the translation results of similar words and phrases used in source language among Android, iOS and Windows mobile phones' manual books

2. To find out the translation technique mostly used in translating the similar words and phrases of Android, iOS and Windows mobile phones' manual books

The research is designed to answer these main problems of the translation of manual book. The questions are formulated as follow:

1. What are the similar words and phrases used in source language between Android, iOS and Windows mobile phones' manual books?

2. What techniques are mostly used in translating the similar words and phrases of Android, iOS and Windows mobile phones' manual books? 


\section{LITERATURE REVIEW}

There are five previous projects related to the research reviewed. It aims to find the gaps, strength and weakness. It is helpful for this project to fill in the gaps and to be a different project. The five previous projects summarized into the following paragraphs.

First, project written by Dewi (2010) that is about translation process of some English information technology terms into Indonesian. Second is project by Prawiradireja (2011) entitled An Analysis of Translation Porcedure in Handphone Nokia Express Music 5300 and Motorola L6 user's Guide Books. The third project is made by Novalina (2011) entitled $A$ Comparative Analysis between Online Translation (Google Translate), Students', and Professional's Translation. The next is project by Cahyono (2012) entitled Translation Techniques Used in GT-B321O Samsung's User Manual. The last is a final project by Setiawan (2012) entitled An Analysis of Manual Book of Nokia 110 in translating from English into Bahasa Indonesia. From those similar studies, the weaknesses are some of them did not explain very detail for the analysis instead of it is useful for readers to easy understand and most of them did not compare the one manual book to another, to get which one manual book has good translation.

Based on Molina \& Albir (2002) there are eighteen techniques of translation that have its explanation, which are Adaptation, Amplification, Borrowing, Calque, Compensation, Description, Discursive Creation, Establish Equivalent, Generalization, Linguistic Amplification, Linguistic Compression, Literal Translation, Modulation, Particularization, Reduction, Substitution, Transposition and Variation. Those translation techniques are applied in the research for finding out the kinds of translation technique used in translating 3 OS mobile phones' manual books.

\section{METHODOLOGY}

The First step, to conduct this research is collecting the data. There are some ways for collecting data in terms of collecting the manual books owned and internet source. In collecting the manual books owned by people is the precisely one ways and easy to do since nowadays every person has mobile phone and absolutely it has the manual books. Meanwhile since, not all mobile phones' manual books needed have been owned by around people, 
soft copy of the manual books can be searched in internet for getting easy the research in collecting the data.

The next step analyzing those data. The step in analyzing the data can be seen as follows: selecting the data, reading the manual books, identifying the similar words and phrases at each part of the manual book, identifying the translation technique used in translating mobile phones' manual books, recording the similar words and phrases and translation technique found into table form and the last is conclusion.

\section{RESULT AND DISCUSSION}

\section{Similar words and phrases}

The first research question of this final project is what the translation results of similar words and phrases used in source language among Android, iOS and Windows mobile phones' manual books are and this research has answered the question. From the data, there were 100 similar words and phrases used. Besides the similar words and phrases, there were also 24 similar meaning in different words and phrases. Here are similar meaning in different words and phrases.

\begin{tabular}{|c|c|c|c|}
\hline No & $\begin{array}{c}\text { Source Language } \\
\text { (English) }\end{array}$ & $\begin{array}{c}\text { Target Language } \\
\text { (Indonesian) }\end{array}$ & Application types \\
\hline \multirow{3}{*}{1} & Safety Information & Informasi keselamatan & Android \\
\hline & $\begin{array}{ll}\text { Important } & \text { Safety } \\
\text { Information } & \end{array}$ & $\begin{array}{l}\text { Informasi penting mengenai } \\
\text { keselamatan }\end{array}$ & $I O S$ \\
\hline & Safety & Keselamatan & Windows \\
\hline \multirow{2}{*}{2} & Charging the battery & Mengisi baterai & Android \& IOS \\
\hline & Charge your phone & Mengisi daya ponsel & Windows \\
\hline \multirow{2}{*}{3} & Touch Screen & Layar sentuh & Android \& Windows \\
\hline & Multi touch screen & Layar multi touch & $I O S$ \\
\hline \multirow{2}{*}{4} & Volume button & Tombol volume & Android \& IOS \\
\hline & Volume keys & Tombol volume & Windows \\
\hline \multirow{2}{*}{5} & Front camera & Kamera depan & Android \& Windows \\
\hline & FaceTime camera & Kamera FaceTime & $I O S$ \\
\hline \multirow{3}{*}{6} & Rear Camera & Kamera belakang & Android \\
\hline & iSight camera & Kamera iSight & $I O S$ \\
\hline & Back camera & Kamera belakang & Windows \\
\hline \multirow{2}{*}{7} & Flash & Lampu kilat & Android \& Windows \\
\hline & LED flash & Kilat LED & $I O S$ \\
\hline \multirow{2}{*}{8} & Back button & Tombol kembali & Android \& IOS \\
\hline & Back key & Tombol kembali & Windows \\
\hline
\end{tabular}




\begin{tabular}{|c|c|c|c|}
\hline \multirow{3}{*}{9} & Power button & Tombol daya & Android \\
\hline & Sleep/wake button & Tombol tidur/bangun & IOS \\
\hline & Power lock/key & Tombol daya kunci & Windows \\
\hline \multirow{3}{*}{10} & Switching to silent mode & Beralih ke mode hening & Android \\
\hline & Silent mode & Tomnol diam & $I O S$ \\
\hline & Switch to silent mode & Mengatur ke modus hening & Windows \\
\hline \multirow{2}{*}{11} & Sending message & Mengirim pesan & Android \\
\hline & Send a message & Mengirim pesan & $I O S \&$ Windows \\
\hline \multirow{3}{*}{12} & Finding contact & Mencari kontak & Android \\
\hline & Find a contact & Menemukan kontak & $I O S$ \\
\hline & Search a contact & Mencari kontak & Windows \\
\hline \multirow{2}{*}{13} & Deleting a contact & Menghapus kontak & Android \\
\hline & Delete a contact & Menghapus kontak & IOS \& Windows \\
\hline \multirow{2}{*}{14} & Taking videos & Merekam video & Android \\
\hline & Record a video & Rekam video / merekam video & $I O S \&$ Windows \\
\hline \multirow{2}{*}{15} & Share photo & Berbagifoto & $I O S \&$ Windows \\
\hline & Sharing image & Berbagi gambar & Android \\
\hline \multirow{2}{*}{16} & Mobile data & Data seluler / data ponsel & Android \& Windows \\
\hline & Cellular data & Data seluler & $I O S$ \\
\hline \multirow[t]{2}{*}{17} & Mobile data connection & $\begin{array}{l}\text { Sambungan data telepon / } \\
\text { koneksi data ponsel }\end{array}$ & Android \& Windows \\
\hline & Cellular data connection & Koneksi data seluler & $I O S$ \\
\hline \multirow{2}{*}{18} & Receiving call & Menerima panggilan & Android \\
\hline & Incoming call & Panggilan masuk & IOS \& Windows \\
\hline \multirow[t]{2}{*}{19} & $\begin{array}{l}\text { Making an international } \\
\text { calls }\end{array}$ & $\begin{array}{ll}\text { Melakukan panggilan } \\
\text { internasional }\end{array}$ & Android \& IOS \\
\hline & International calls & Panggilan internasional & Windows \\
\hline \multirow{3}{*}{20} & $\begin{array}{l}\text { Connecting to a Wi-Fi } \\
\text { network }\end{array}$ & $\begin{array}{l}\text { Menyambung ke jaringan } \mathrm{Wi} \text { - } \\
\mathrm{Fi}\end{array}$ & Android \\
\hline & Connect to Wi-Fi & Menghubungkan ke Wi-Fi & $I O S$ \\
\hline & $\begin{array}{l}\text { Connect to Wi-Fi } \\
\text { Network }\end{array}$ & $\begin{array}{l}\text { Menyambungkan ke } \\
\text { jaringan Wi-Fi }\end{array}$ & Windows \\
\hline \multirow[b]{2}{*}{21} & Rotating the screen & Memutar layar / rotasi layar & Android \& Windows \\
\hline & $\begin{array}{l}\text { Change the screen } \\
\text { orientation }\end{array}$ & Mengubah orientasi layar & $I O S$ \\
\hline \multirow{3}{*}{22} & Searching for location & Mencari lokasi & Android \\
\hline & Find places & Menemukan tempat & $I O S$ \\
\hline & Find a location & Mencari lokasi & Windows \\
\hline \multirow{2}{*}{23} & Mobile network & Jaringan seluler & Android \& Windows \\
\hline & Cellular network & Jaringan seluler & $I O S$ \\
\hline \multirow{2}{*}{24} & Searching the web & Mencari di web & Android \\
\hline & Search the web & Mencari di web & IOS \& Windows \\
\hline
\end{tabular}




\section{Translation technique}

There are 18 translation technique by Molina \& Albir (2002) presented in Chapter 2, with the purpose of answering research question "what techniques are mostly used in translating the same words and phrases of Android, iOS and Windows mobile phones' manual books". The following are the result of identifying translation technique used in translating Android, iOS and Windows mobile phones' manual books as follows:

\section{Android}

Table 1. Translation Technique Used in Android

\begin{tabular}{|c|l|c|c|}
\hline & \multicolumn{3}{|c|}{ ANDROID } \\
\hline No & Translation Technique Used & Quantity & Percentage (\%) \\
\hline 1 & Calque & 35 & $35 \%$ \\
\hline 2 & Establish equivalent & 22 & $22 \%$ \\
\hline 3 & Borrowing & 15 & $15 \%$ \\
\hline 4 & Particularization & 11 & $11 \%$ \\
\hline 5 & Adaptation & 6 & $6 \%$ \\
\hline 6 & Calque \& Borrowing & 4 & $4 \%$ \\
\hline 7 & Calque \& Adaptation & 4 & $4 \%$ \\
\hline 8 & Generalization & 2 & $2 \%$ \\
\hline 9 & Discursive creation & 1 & $1 \%$ \\
\hline \multicolumn{2}{r|}{ Total } & 100 & $100 \%$ \\
\hline
\end{tabular}

This table shows that there are seven translation techniques (Calque, Establish equivalent, Borrowing, Particularization, Adaptation, Generalization \& Discursive creation) and 2 combination of some translation techniques (Calque-Borrowing \& Calque-Adaptation) used in translating 100 similar words and phrases of the Android mobile phones' manual books. Calque stays in first position as the translation technique used with 35 times and 35 percent. 
2. $i O S$

Table 2. Translation Technique Used in $i O S$

\begin{tabular}{|c|l|c|c|}
\hline \multirow{2}{*}{ NO } & \multicolumn{3}{|c|}{ IOS } \\
\cline { 2 - 4 } & Translation Technique Used & Quantity & Percentage (\%) \\
\hline 1 & Calque & 41 & $41 \%$ \\
\hline 2 & Establish equivalent & 25 & $25 \%$ \\
\hline 3 & Particularization & 12 & $12 \%$ \\
\hline 4 & Borrowing & 6 & $6 \%$ \\
\hline 5 & Adaptation & 4 & $4 \%$ \\
\hline 6 & Calque \& Borrowing & 4 & $4 \%$ \\
\hline 7 & Calque \& Adaptation & 4 & $4 \%$ \\
\hline 8 & Generalization & 2 & $2 \%$ \\
\hline 9 & Discursive creation & 1 & $1 \%$ \\
\hline 10 & Amplification & 1 & $1 \%$ \\
\hline \multicolumn{2}{|c|}{ Total } & 100 & $100 \%$ \\
\hline
\end{tabular}

This table displays that there are eight translation techniques (Calque, Establish equivalent, Particularization, Borrowing, Adaptation, Generalization Discursive creation \& Amplification) and 2 combination of some translation techniques (Calque-Borrowing \& Calque-Adaptation) used in translating similar words and phrases of iOS mobile phones' manual books. In short, the high position of translation technique used is Calque technique with 41 times and 41 percent.

\section{Windows}

Table 3. Translation Technique Used in Windows

\begin{tabular}{|c|l|c|c|}
\hline \multirow{2}{*}{ NO } & \multicolumn{3}{|c|}{ WINDOWS } \\
\cline { 2 - 4 } & \multicolumn{1}{|c|}{ Translation Technique Used } & Quantity & Percentage (\%) \\
\hline 1 & Calque & 39 & $39 \%$ \\
\hline 2 & Establish equivalent & 28 & $28 \%$ \\
\hline 3 & Particularization & 17 & $17 \%$ \\
\hline 4 & Borrowing & 4 & $4 \%$ \\
\hline 5 & Adaptation & 4 & $4 \%$ \\
\hline 6 & Calque \& Adaptation & 4 & $4 \%$ \\
\hline 7 & Calque and borrowing & 2 & $2 \%$ \\
\hline 8 & Discursive creation & 1 & $1 \%$ \\
\hline 9 & Amplification & 100 & $1 \%$ \\
\hline \multicolumn{2}{|c|}{ Total } & & $100 \%$ \\
\hline
\end{tabular}


This table displays that there are seven translation techniques (Calque, Establish equivalent, Particularization, Borrowing, Adaptation, Discursive, creation \& Amplification) and 2 combination of some translation techniques (Calque-Borrowing \& Calque-Adaptation) used by translator in translating similar words, phrases, and sentences of Windows mobile phones' manual books. Based on the table, calque is the translation technique mostly used with the quantity is 39 times and 39 percent.

\section{Brief description about techniques used}

This part discusses the translation techniques only used in translating the similar words and phrases of 3 OS mobile phones' manual books. Discussion of those techniques as follows:

1. Adaptation

Translators translate similar words and phrases use adaptation as the technique for changing the cultural aspect from SL (English) to TL (Indonesian). For example, translating overview into selayang pandang in Indonesian. Meaning of overview in Indonesia based on dictionary is actually ikhtisar but translators changed it into selayang pandang (means sepintas pandang) based on their culture. Thus, it translated in relation to target culture.

\section{Amplification}

Translators translate source language by introducing details in TL that are not formulated in SL. For instance, earpiece translated into lubang suara, the source language, earpiece is actually not recognized in dictionary, so translator used lubang suara for introducing the SL.

3. Borrowing

Borrowing is a technique which is used for taking straight the SL and it can be used for taking the pronunciation only from SL into TL. For example, translators took straight speaker, earpiece, calendar, etc in SL to TL without changing and it also took the pronunciation from SL such as microphone becomes mikrofon, history becomes histori, etc.

4. Calque

Calque is literal translation of phrase or foreign word which are translated from English into Indonesian. The examples of translating similar words and phrases that used calque as the translation technique are phone number translated to nomor telepon, touch screen translated to layar sentuh, etc. 
5. Discursive creation

Discursive creation is the establish equivalent that is totally unpredictable out of context. The examples of translating similar words and phrases that used Discursive creation as the translation technique are 'playlist' translated into 'daftar pustaka', it was really different because meaning of 'playlist' is actually list of music, while, 'daftar pustaka' means reference/source. Headset jack into colokan headset in Indonesian, headset jack means a jack for setting the headset to mobile phone, but translator changed it into colokan which is really different thing, colokan in Indonesia means a part of headset to be entered to the jack in mobile phone. Thus, Its really different and unpredictable translation.

6. Establish equivalent

Establish equivalent is a translation technique which use term or expression recognized in dictionary. The examples of translating similar words and phrases that used calque as the translation technique are warning translated to peringatan, overview, translated to ikhtisar, message translated to pesan, battery translated to baterai, and they were recognized in dictionary.

7. Generalization

Translator used Generalization for using more general or neutral term. For example, alert in SL translated to peringatan, peringatan is actually able to translate in English in many ways into warning, alert and reminder.

8. Particularization

Here is the example of translating similar word, phrase or sentence used particularization as the translation technique. Particularization is used by translator to make the TL precisely or to be concrete term. This technique is in opposition to Generalization. For example, home button translated to tombol mulai, and home screen translated to layar awal. Home button is actually able translate to tombol awal but translators used tombol mulai for using a phrases precisely as well as home screen is able to translate to layar mulai but translators prefer to use layar awal.

To summarize those techniques, there are 8 translation techniques used in Android, iOS and Windows mobile phones manual books. They are adaptation, amplification, borrowing, calque, establish equivalent, discursive creation, generalization, and particularization. 


\section{CONCLUSION AND RECOMMENDATION}

As stated before, the objectives are to find out the similar words and phrases among Android, iOS, and Windows mobile phones' manual books and the last is to find out the translation technique mostly used in translating the data. According to the results and discussion of the research, it can be concluded that there are 100 similar words and phrases found and there are 8 translation technique used; adaptation, amplification, borrowing, calque, establish equivalent, discursive creation, generalization, and particularization and the mostly used is calque with the percentage are 35\% in Android, $41 \%$ in iOS and 39\% in Windows mobile phones' manual books.

After conducting the research, there are some recommendations for readers who want to conduct a research related to this study. First, it is better if a further research analyze more than 3 OS mobile phones manual book. Second, for knowing whether the translation of 3 OS manual books is good or not, it is better if a further research also analyze the three aspect of good quality translation; they are accuracy, acceptability and readability.

\section{REFERENCES}

- $\quad$ Cahyono, M. C. (2012). Translation techniques used in GT-B3210 samsung's user manual. Semarang: Universitas Dian Nuswantoro Semarang

- $\quad$ Dewi, P. H. (2010). An analysis of the translating process of some English information technology terms into Indonesian. Unpublished Diploma 3 Final Project. Bandung: Politeknik Negeri Bandung.

- Molina, L., \& Albir, A. H. (2002). Translation technique revisited: A dynamin and functionalist approach. XLVII(4)

- Novalina, A. (2011). A comparative analysis between online translation (google translate), students', and professional's translation. Unpublished Diploma 3 Final Project. Bandung: Politeknik Negeri Bandung.

- $\quad$ Prawiradireja, N. S. (2011). An analysis of translation porcedure in hand phone nokia express music 5300 and motorola L6 user's goude books. Unpublished Final Project. Jakarta: Universitas Islam Negeri .

- $\quad$ Setiawan, R. (2012). An analysis of manual book of nokia 110 in translating from English into Bahasa Indonesia. Mataram: Universitas Mataram. 